vol. 34 - $n^{\circ} 1 \mid 2018$

Mouvements migratoires d'hier et d'aujourd'hui en Italie

\title{
Migrants or Refugees? The Evolving Governance of Migration Flows in Italy during the "Refugee Crisis"
}

Migrants ou réfugiés? L'évolution de la gouvernance des flux migratoires en Italie au cours de la "crise des réfugiés " ¿Migrantes o refugiados? La evolución de la gobernanza de los flujos migratorios en Italia durante la «crisis de los refugiados»

\section{Elena Ambrosetti and Angela Paparusso}

\section{(2) OpenEdition}

\section{Journals}

Electronic version

URL: https://journals.openedition.org/remi/10265

DOI: 10.4000/remi.10265

ISSN: $1777-5418$

\section{Publisher}

Université de Poitiers

\section{Printed version}

Date of publication: 1 April 2018

Number of pages: 151-171

ISBN: 979-10-90426-61-0

ISSN: 0765-0752

\section{Electronic reference}

Elena Ambrosetti and Angela Paparusso, "Migrants or Refugees? The Evolving Governance of Migration Flows in Italy during the "Refugee Crisis"', Revue européenne des migrations internationales [Online], vol. $34-n^{\circ} 1$ | 2018, Online since 28 December 2019, connection on 19 April 2022. URL: http:// journals.openedition.org/remi/10265 ; DOI: https://doi.org/10.4000/remi.10265 


\section{Migrants or Refugees? The Evolving Governance of Migration Flows in Italy during the "Refugee Crisis"}

\section{Elena Ambrosetti ${ }^{1}$ and Angela Paparusso ${ }^{2}$}

The need to escape persecution and search for better living conditions has pushed people to migrate for decades, and not only to Europe. At the global level, the number of forcibly displaced people has increased over time, passing from 37.3 million in 1996 to 65.6 million in 2016 (UNHCR, 2017). If we focus our attention on recent years, the numbers are even more impressive: 35.4 million in 2011, 42.8 million in 2013 and 54.9 million in 2014. In the Mediterranean area, this trend is mainly due to the Arab Spring, which increased instability in the region and progressively led to the Libyan and Syrian crises. In 2016, 710,400 asylum seekers were granted protection by member states of the European Union (EU), more than double the number for 2015. The largest groups of beneficiaries of asylum in the EU member states are citizens of Syria, Iraq and Afghanistan. Border fortification and the securitization of migration have been the main policy approaches, confirming a consolidated policy routine at EU level. It has been argued that framing migration as a "crisis" served the EU so that it could consolidate routine policy practices, such as tight border control, with the direct consequence of preventing people from seeking safe and legal routes into the EU (Jeandesboz and Pallister-Wilkins, 2016). This fortification has manifested itself through various forms: the erection of walls across member states, the "hotspot approach", resettlement and intra-EU relocation schemes (around 14,000 refugees have been resettled among the EU member states) and, finally, a multilateral policy on cooperation and development with the migrants' origin and transit countries (externalization or extra-territorialization of migration movements and policies).

The 2015 and 2016 "refugee crisis" has been defined as a crisis in the governance of people asking for international protection, but also as a crisis of the European common policy on migration and asylum, with national approaches often prevailing over the communitarian one. Therefore, in general,

1 Professor, Faculty of Economics, La Sapienza University, Via del Castro Laurenziano 9, 00161 Rome, Italy; elena.ambrosetti@uniroma1.it

2 Post-doctoral researcher, Institute of Research on Population and Social Policies, IRPPSCNR, Via Palestro 32, 00185, Rome, Italy; angela.paparusso@irpps.cnr.it

We are grateful for financial support from the University of Rome La Sapienza H2020

Grant "EU-MED relations: cooperation, borders and migration". 
the "refugee crisis" has proven that more efforts are required to strengthen the global governance of migration (Wihtol de Wenden, 2013; Wihtol de Wenden and Ambrosetti, 2016); in particular, it has confirmed the need to introduce a policy able to equally distribute the burden of asylum seekers among the EU countries. Indeed, the Dublin Convention is not able to determine in which countries asylum applicants should be hosted. According to the Dublin Convention, asylum applications should be examined by the state that played the most important role in each applicant's entry. This produces a double burden for Italy, Greece and Hungary because they are on the front line and restrictions for those migrants who instead want to reach northern European countries, such as Germany or Sweden, where they already have a family or social and economic networks.

In its initial experience as an immigration country, Italy had only received small numbers of asylum seekers, while the bulk of immigration growth was linked to massive inflows of labour migrants and their families. Until the late 2000s, and the reception of EU directives on asylum, Italy did not have what could be described as a comprehensive normative framework on the issue. The so-called refugee crisis has changed these features overwhelmingly. Unlike what has been observed in Greece, where most incoming migrants reasonably qualify for international protection, the situation in Italy is one where making a clear-cut categorization of refugees and (economic) migrants is arguably more challenging. Cross-Mediterranean flows to Italy are mixed in kind, with highly diverse individual profiles (in terms of gender, age, vulnerabilities, etc.), original motivations or migratory trajectories and experiences, which are difficult to unravel. In such a context, how have Italian policies reacted to the increasing magnitude and complexity of mixed flows across the Mediterranean? What has the role of internal and external actors been in orienting the political response to the "crisis"? Has Italy turned from a labour migration magnet to a land of the asylum? In this contribution, we will address these questions by presenting the evolution of migration flows and stocks in Italy in recent decades and by analysing the policy responses adopted by the Italian authorities. Lastly, we will highlight the role of external actors (such as the EU and other European partners) in influencing the Italian asylum and migration policies. The current situation will be analysed by looking at the recent Italian migration experience from a historical perspective.

From the theoretical point of view, Italy belongs to the so-called southern European model of immigration, together with Greece, Portugal and Spain (King et al., 2000; Arango and Finotelli, 2009). These countries are characterized by a relatively recent immigration history: mainly emigration countries until the mid-1970s, they started to receive mass immigration in the 1990s (Freeman, 1995). Some common features, as far as the management of migration inflows is concerned, characterize the countries embedded in this model. In particular, one can observe a lack of selective immigration policies, a large underground economy attracting undocumented immigrants, a strong segmentation of the labour market and the use of ex-post instruments to provide a legal status to immigrants, such as regularizations, quota systems and flow decrees. To sum up, the main common characteristics of this model are a) the timing and the size of inflows, b) the reasons for and the modes of entry and c) the distinctive manner of integration into the local labour market (Peixoto et al., 2012; Di Bartolomeo et al., 2016; Fellini and Fullin, 2016). In the next section, we will provide an 
overview of the first characteristics. In the following sections, we will concentrate on the second ones, focusing on the evolution over time of immigration policies in Italy and on the evolution of trends and patterns of immigration. In doing so, we will shed light on the complex relationship between policy and immigration in the context of an economic downturn and political instability in both the sending and receiving countries. Finally, we will question whether the southern European model of immigration is still the right theoretical framework to describe immigration in Italy.

\section{Italy: A Recent but Consolidated Immigration Country}

Italy turned into an immigration country in the late 1970s. Due to its geographical position at the southern border of Europe, Italy is one of the most important entry points and one of the major immigrant destinations in the EU, despite the recent economic crisis (Pastore and Villosio, 2011). The foreign resident population rose from 737,793 in 1996 to 2,419,483 in 2006 and 5,026,153 in 2016 and it represents around $8.3 \%$ of the total population (Figure 1). This number rises to 6 million (around $10 \%$ of the total population), considering non-resident legal and illegal migrants (ISMU, 2017). Illegal migration also forms a significant component of the total immigrant population. We can observe a series of ups and downs in the illegal migration trends over the years corresponding to the adoption of periodical amnesties by the Italian governments (Figure 2).

Figure 1: Evolution of the Foreign Resident Population in Italy (1996-2016)

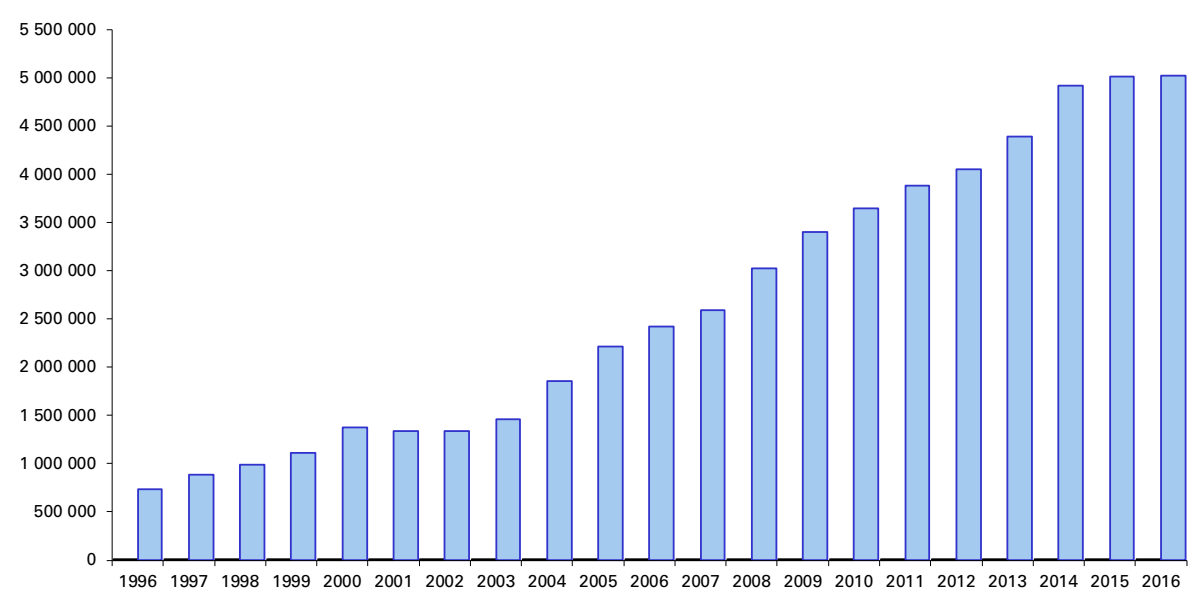

Source: ISTAT, 2017. 
Figure 2: Estimates of the Foreign Population Illegally Residing in Italy by Status (1991-2016)

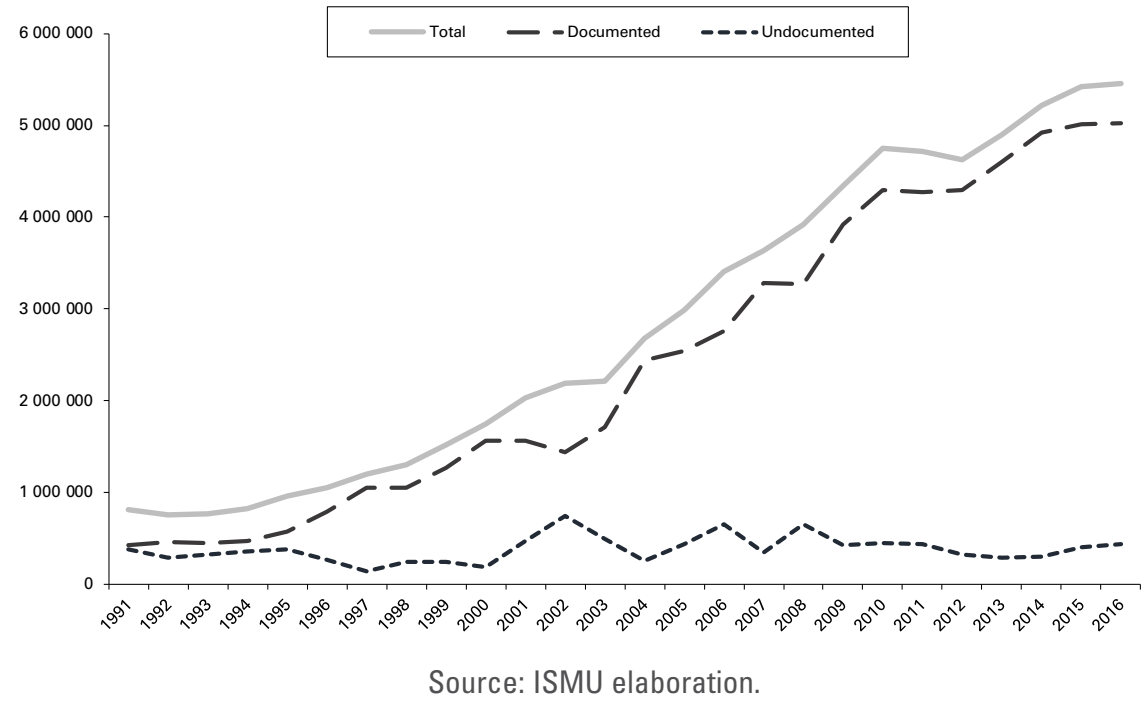

Figure 3: Distribution (in \%) of Foreign Resident Population in Italy by Citizenship of Origin (2016)

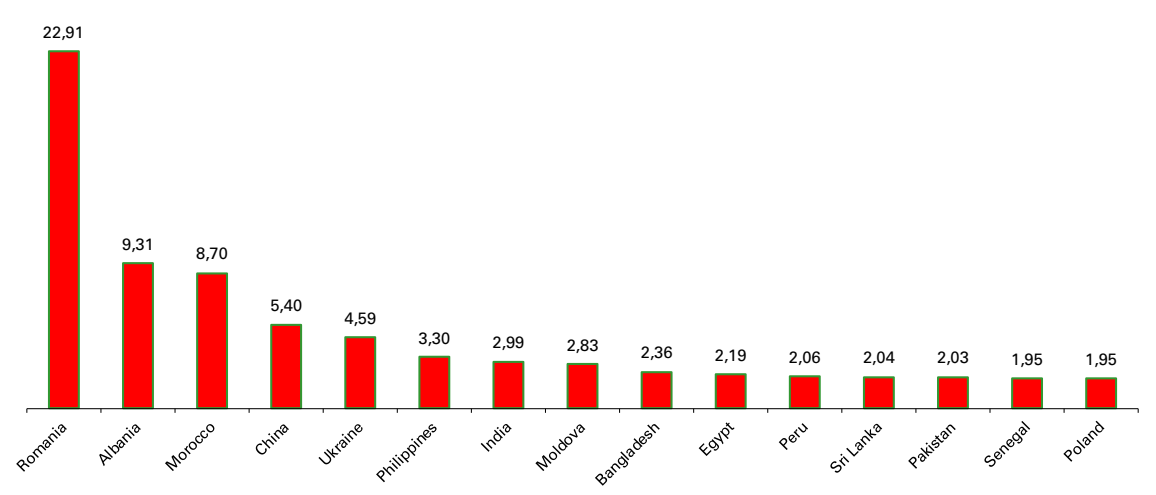

Source: ISMU elaboration of ISTAT data. 
Figure 4: Distribution (in \%) of Foreign Resident Population

in Italy by Citizenship of Origin and Gender (2016)

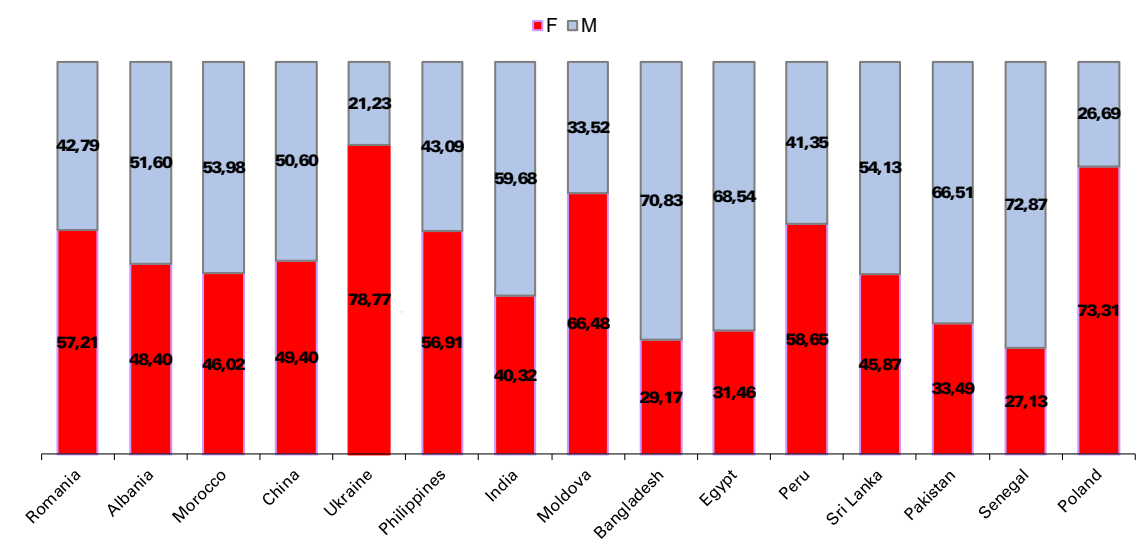

Source: ISMU elaboration of ISTAT data.

The migrants living in Italy mainly come from Romania, Albania, Morocco, China and Ukraine (Figure 3). Together they form 50.9\% of the total immigrant population. At first, the migrants came from North Africa (Morocco, Tunisia and Egypt). More recently, a strong inflow of migrants from eastern European countries (Romania and Albania) and, to a lesser extent, East Asian countries (China and the Philippines) have arrived in Italy, although North Africa (Morocco) remains an important area of origin for migrants living in Italy. While most nationalities show a gender balance, for others, such as Ukraine and the Philippines, the migration is dominated by females, and for others, such as Senegal, Bangladesh, Egypt and Pakistan, the migration is dominated by males (Figure 4). This reflects the existence of different migration projects, lengths of stay, and cultural and economic factors at both the place of origin and destination.

Italy is attractive to immigrants because entering the country and working has always been particularly easy even without a permit of stay for work reasons. Illegal work constitutes an important "pull factor" at least in the first stage of immigration, as later on most immigrants manage to regularize their position and enter the legal economy through their willingness to take on low-skilled jobs (OECD, 2005). In general, the employment rate of immigrants between 2004 and 2016 was consistently higher than the rate among Italians. From a gender perspective, the employment rate of male immigrants is higher than the rate among Italians, although since 2009 it has witnessed a significant drop (12.5 percentage points), due to the strong impact of the economic crisis. In the same period, the employment rate of Italian males suffered a decline due to the same reasons albeit to a lesser extent than immigrants (about 3 percentage points). The employment rates of female immigrants are also higher than those of Italian women: in this case, however, we note that over the past few years and particularly since 2009, the rate among immigrant women has fallen by about 1.5 percentage points. Conversely, the employment rate of Italian women increased by about 2 percentage points. 
As far as the sector of activity is concerned, immigrants are employed in sectors with low professional requirements and in low-skilled jobs. As a result, immigrant workers have been more affected by the economic crisis than Italian workers: their employment rate has decreased and the unemployment rate increased. In the period from 2008 to 2016, the latter went from $6 \%$ to $14 \%$ for male immigrant workers and from $12 \%$ to $17 \%$ for female immigrant workers. In the same period of time, the unemployment rate among both male and female Italian workers also increased, but to a lesser extent compared to immigrants (from $5.5 \%$ to $10.5 \%$ for men and from $8 \%$ to $12 \%$ for women). Among immigrant workers, there is a marked tendency to be over-educated for their employment position: about $30 \%$ of male immigrant workers and $50 \%$ of female immigrant workers perform work activities for which lower levels of education would be sufficient. This phenomenon is less relevant for Italian workers, affecting just $21 \%$ of Italian men and $22 \%$ of Italian women (ISTAT-Labour Force Survey). From these brief considerations, it is clear that although the role and the numerical importance of immigrant workers in the Italian labour market have increased over time, their integration process is characterized by many difficulties: as a result, immigrants often occupy low-skilled jobs in the industrial and services sectors of the labour market. The impact of immigration on the Italian labour market has been beneficial for Italian workers: thanks to the entry of immigrant workers, they have been able to occupy more qualified positions, carrying out more complex tasks and leaving low-skilled working positions to immigrant workers. Furthermore, the employment of immigrant workers, mostly in activities linked to care services, has favoured the employment of Italian women, as they have been at least partly relieved of the role to which they were traditionally relegated.

\section{The Italian Experience with Refugees and Economic Migrants until the End of the 1990s}

In Italy and the other countries belonging to the southern European model, immigration began in the 1970s, in a situation of no legislation on immigration. At that time, most immigrants were "illegals" without residence permits. At the beginning of the 1980s, the increasing number of foreign residents in Italy and the ratification by the Italian government in 1981 of the ILO Convention on immigrant workers (Colombo and Sciortino, 2004) highlighted the need for comprehensive legislation on immigration. One of the first attempts to regulate the employment of non-EU immigrants was the Di Giesi Bill of 1982. In the same year, 5,000 illegal workers were regularized: it was the second time since 1977 that such a legal instrument had been adopted to cope with illegal migration (Einaudi, 2007).

After a long process, Act no. 943 of 30 December 1986 - the so-called Foschi Law - was approved. The main aim of the new legislation was to prevent illegal immigration, by introducing new rules for employers hiring non-EC workers. The Foschi Law introduced family reunion for the first time, and it allowed the regularization of 120,000 illegal migrants (Zincone, 1998: 49). The new rules introduced for hiring non-EC workers were considered quite restrictive, because according to the law, employers had to prove that there were no Italian or EC workers who could fill that job (Zincone and Caponio, 2006). However, at that time the Italian 
borders were quite permeable, and immigrants could easily enter the country without a visa and work on the black labour market (Colombo and Sciortino, 2004). The period between the end of the 1980s and the beginning of the 1990s, following the fall of the Iron Curtain, was characterized by an increasing number of immigrants entering Italy. At that time, Italy was also involved in the implementation of the Schengen Treaty (1993), therefore, to comply with this new European policy, Italy had to manage its external borders more effectively (Einaudi, 2007; Pastore et al., 2006). These two factors pushed Italy to adopt new legislation on immigration in 1990, in the form of the Martelli Law. The new law was the first systematic law on immigration as it addressed all kinds of migration motives and not only labour migration as the previous laws had done. Indeed, for the first time, the Martelli Law systematically introduced the right to asylum in Italy (Art. 1). One of the main purposes of the new legislation was to regulate entry to Italian territory: to pursue this goal a compulsory entry visa was introduced for non-EC citizens and measures were enforced to control the borders and expel illegal immigrants. The second purpose of the law was to regularize the immigrants already present in the Italian territory; therefore, it stated that all non-EC immigrants present in Italy before 31 December 1989 could apply for regularization regardless of their employment position. Overall, the amnesty allowed the regularization of 218,000 immigrants.

1995 saw the introduction of the third reform concerning migration in less than ten years: the Dini Decree. In the end, the decree was declared unconstitutional; hence, few articles of the reform were applied. More specifically, a new amnesty was promulgated, in order to regularize both illegal workers and family migrants. Altogether, over 250,000 immigrants were regularized, therefore the total number of immigrants regularized in a decade amounted to over 580,000.

It seems that the more restrictive measures enacted to control the borders as of the beginning of the 1990s were not effective as the number of illegal immigrants continued to increase over the years and at the same time the Italian government continued to use amnesties to regularize their position. Indeed, the immigrants showed a good capacity for adapting their survival strategies according to the new legislation introduced over the years. During the 1970s and the 1980s they could easily enter Italy without a visa, and once visas were introduced by the Martelli law in 1990, immigrants entered Italy holding a tourist visa. From this point on, the phenomenon of overstayers spread greatly. Even though the way to enter Italy had to be modified compared to the past because a visa had become mandatory, as in the past a good part of the illegal immigrants applied for one of the amnesties and were able to get residence permits. The number of residence permits issued for work reasons increased constantly over the first half of the 1990s. However, the number of illegal immigrants was also stable over the same period (see Figures 2 and 7 and Tables 1 and 2). In fact, in Italy, like in the other southern European countries, the existence of a vast black labour market made it possible for many illegal migrants to make ends meet. Without such a big and widespread illegal economy, the unauthorized immigrants would have soon left Italy to go back to their countries of origin. Indeed, Italy and the other southern European countries were particularly attractive to immigrants because it was quite easy to enter and live in these countries without a residence permit for work reasons (Baganha, 1998; Reyneri, 1998 and 2001; Baldwin-Edwards and Arango, 1999). Eventually, most of the illegal immigrants 
got regularized and were incorporated into the regular economy where they could occupy several niches of the labour market that were in need of low-skilled workers (OECD, 2005).

The second half of the 1990s can be considered a turning point for the legislation on migration in Italy. At that time, the lack of comprehensive legislation on migration became a critical issue both at the national and at the international level. The Italian government had to deal with a public opinion that was fiercely convinced that it was unable to control migration or fight against illegal migration. The same opinion was also shared, to a lesser extent, by the European governments. In this regard, Italy had entered the Schengen Agreement in 1990, however, it had not yet redefined its migration policies according to the European mainstream. Thus, a long process of policy-making started in the mid-1990s, and finally, in 1998 the Single Act of Immigration law was approved, better known as the Turco-Napolitano Law. According to Zincone and Caponio (2006: 4), the Turco-Napolitano Law was based on four pillars: 1. fighting and preventing illegal immigration through the immediate expulsion of illegal migrants; in addition, illegal migrants waiting for expulsion had to be detained in Temporary Stay Centres (CPT); 2. managing labour migration through the introduction of a quota system, established each year by the Ministry of Labour, and introducing a "sponsor system", through a special settlement permit for entering Italy to look for a job; 3. establishing a "National Integration Fund" with the aim of fostering the integration of migrants through the funding of multicultural activities and the introduction of the permanent residence permit for those migrants residing in Italy for five years; 4. granting basic human rights, such as basic health care, to illegal migrants. Like the past legislation, the Turco-Napolitano Law introduced an amnesty for non-EU illegal workers present in Italy on 27 March 1998. 270,000 immigrants were regularized under the fourth amnesty issued in 12 years, bringing the total number of immigrants regularized since 1982 to more than 800,000 (Table 2). The entry into force of the Dublin Convention in 1997 and the need to deal with the migration crisis arising from the Kosovo conflict led Italy to adopt the "Common Action" project ("Azione Comune") in 1999. The first consultations between the Minister of the Interior, several non-governmental organizations and the National Association of Italian Municipalities (ANCI) started in 2000. These were aimed at understanding how to effectively develop this project and how to manage the arrivals of people asking for international protection in the Italian territory. As a result, the National Asylum Programme was approved and started in 2001 with the agreement of the United Nations High Commissioner for Refugees (UNHCR).

At the end of the millennium and after the introduction of new comprehensive legislation on immigration, the picture described in the previous paragraphs was largely unchanged. Immigration to Italy was mainly labour-oriented because there was a strong labour demand in a segmented work market where immigrants could easily find a job. However, there was not an active policy on immigration; hence, most immigrants entered the country illegally. Later on, they would be regularized after spending a more or less short period working on the black labour market. 
Over the years, the number of family immigrants has more than doubled (Table 1), showing that immigration is becoming a stable phenomenon in Italy. Other categories of immigrants, and in particular asylum-related immigrants, have increased in number. However, they are still quite insignificant, representing about $1 \%$ of the total number of immigrants.

Figure 5: Distribution (in \%) of Stock of Residence Permits Issued by Motive in Italy (1992-2007)

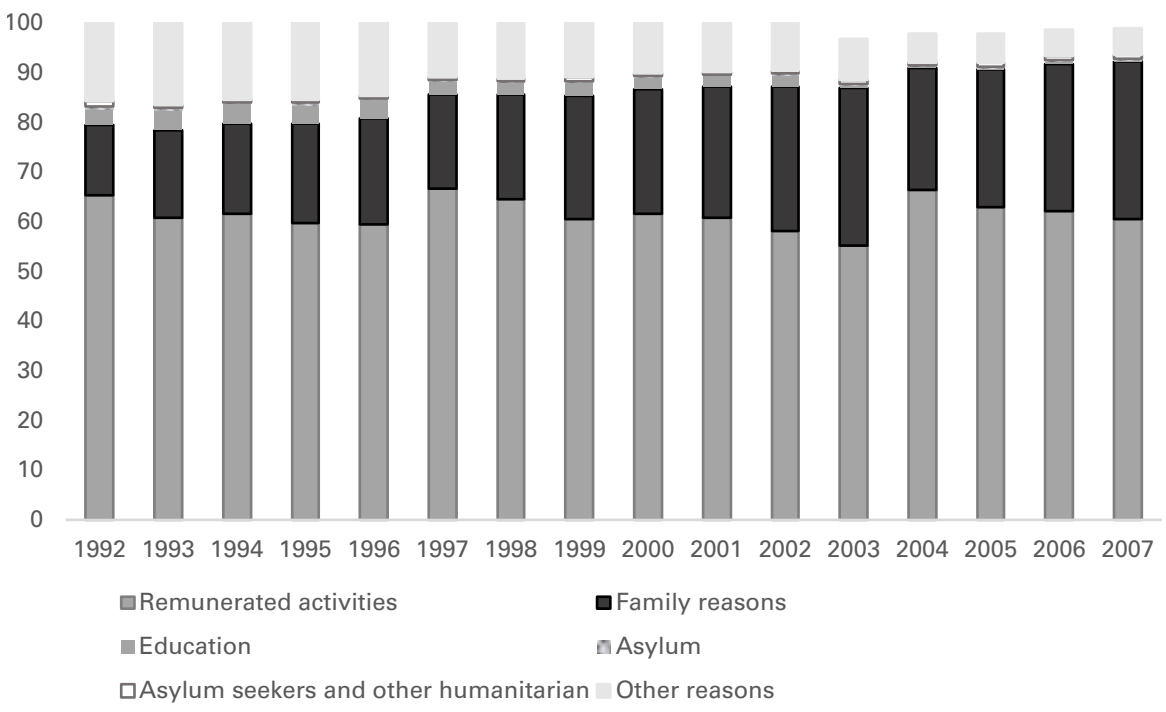

Source: Own elaboration of ISTAT data.

Table 1: Distribution (N and \%) of Stock of Residence Permits Issued by Motive (1997-1992, 2002-1997, 2007-2002)

\begin{tabular}{lccccc}
\hline & $\begin{array}{c}\text { Remunerated } \\
\text { activities }\end{array}$ & Family reasons & Education & Asylum & $\begin{array}{c}\text { Asylum } \\
\text { seekers } \\
\text { and other } \\
\text { humanitarian } \\
\text { reasons }\end{array}$ \\
\hline $\begin{array}{l}\text { Diff. 1997-1992 } \\
\% \text { variation }\end{array}$ & 232608 & 95935 & 5339 & -1226 & -1874 \\
$\begin{array}{l}\text { 1997-1992 } \\
\begin{array}{l}\text { Diff. 2002-1997 } \\
\% \text { variation }\end{array}\end{array}$ & 54.9 & 104.2 & 25.2 & -31.1 & -29.2 \\
$\begin{array}{l}\text { 2002-1997 } \\
\text { Diff. 2007-2002 }\end{array}$ & 28.1 & 233753 & 6731 & 3091 & 4485 \\
$\%$ variation & 742092 & 341983 & 18410 & 113.6 & 98.6 \\
$2007-2002$ & 74.0 & 81.1 & 55.4 & 48.2 & 11878 \\
\hline
\end{tabular}

Source: Own elaboration of ISTAT data. 
Table 2: Number of Immigrants Regularized in Italy (1982-2012)

\begin{tabular}{cc}
\hline Year & Number \\
\hline 1982 & 5000 \\
1986 & 120000 \\
1990 & 218000 \\
1995 & 250000 \\
1998 & 217000 \\
2002 & 646000 \\
2009 & 222000 \\
2012 & 23000 \\
Total & 1701000 \\
\hline Source: Own elaboration.
\end{tabular}

\section{Italy's History of Refugees and Economic Migrants in the New Millennium}

As pointed out in the previous paragraph, the EU has played an important role in the definition of the Italian immigration policy. This was particularly true at the beginning of the new millennium: the advancement of the common EU immigration policy and in particular the implementation of the SchengenTreaty served as push factor for Italy to better protect its borders and to regulate immigration more effectively, also with the aim of no longer being considered the weak border of the EU (Einaudi, 2007; Pastore et al., 2006). It was with this spirit that a modification of the Single Act of 1998 occurred in 2002, under the name of the Bossi-Fini Law (189/2002). In particular, this law introduced the "unified contract of employment and residence", which linked the right to residence of an immigrant in Italy to his/her work contract: once the latter expired, the immigrant had to quickly find a new job in order to continue to live in Italy (Zincone, 2006). Moreover, it established that the employer had to provide proper housing and cover the costs of the employee's return to the country of origin in the event of dismissal. The "sponsor"' system, one of the main innovations of the Turco-Napolitano Law, was abolished. As far as the fight against illegal migration was concerned, the Bossi-Fini Law laid down a stricter enforcement of compulsory repatriation. The period of stay in the Temporary Stay Centres (CPT) was prolonged and detention was also introduced for overstayers. Finally, an important amnesty was established: it was addressed to non-EU foreigners who had been working illegally in Italy for at least three months before the law came into force (July 2002). With 646,000 immigrants whose position was regularized (Ministry of the Interior), this amnesty is considered the second biggest regularization ever realized in Europe (after the Spanish one), demonstrating the existence of a certain policy continuity. Amnesties thus became a distinctive feature of the Italian management of migration, contributing to the definition of the aforementioned southern European model of immigration. The Bossi-Fini Law recognized the aforementioned National Asylum Programme, transforming it into the Protection System 
for Asylum Seekers and Refugees (SPRAR), and launching the National Fund for Asylum Policy and Services, financed by the Ministry of the Interior. The SPRAR was recognized as the sole national system tasked with supporting, protecting and integrating asylum seekers, refugees and migrants who fell under other forms of humanitarian protection in Italy. Since 2006, the SPRAR has been open to all local authorities who are interested in presenting asylum-related projects with its financial support, according to a three-year schedule. As further proof of this policy continuity, no big changes have occurred in Italy since the Bossi-Fini Law, making the Turco-Napolitano Law, and its modifications introduced by Law no. 189/2002, the main legal reference for immigration in Italy. The main provisions following the Bossi-Fini Law can be summarized according to two types: the treatment of undocumented migrants together with the regularization of undocumented migration through amnesties, and the execution of EU directives and changes to the existing laws. For instance, Legislative Decree no. 5/2007 executed an EEC Directive about family reunification, now granted according to the effectiveness of family ties proven by showing official documents, such as marriage and birth certificates. Legislative Decree no. 25/2008 introduced the Asylum Seekers Reception Centre (CARA) for asylum seekers who had illegally crossed the Italian borders, who reside illegally in Italy, who are not in possession of identity documents or whose nationality cannot be verified. The period of stay in these centres should not exceed thirty-five days, but these conditions are often violated with periods of stay that are longer than 150-180 days. Moreover, since 2001 a series of directives on asylum have been approved by the European Council and implemented by the Italian legislator, such as Directive 2001/55/ EC on temporary protection, Directive 2003/9/EC on the minimum standards for asylum in the EU member states, Directive 2004/83/EC on the recognition of refugee status, Directive 2005/85/EC on the recognition and revocation of refugee status, and Directive 2011/95/EU, which harmonized the status of international protection.

In 2009, the centre-right coalition introduced the "safety package", a set of laws aimed at controlling the entry of unauthorized migrants from other EU member states. Ethnic Roma, already discriminated by national and local policies aimed at relegating them to segregated camps, were the most affected by this package of laws. Within this policy framework, security patrols were organized by municipal governments to control public areas, contributing to the rise of anti-immigrant sentiments and protests among citizens. A new amnesty was introduced in 2009, regularizing 222,000 immigrants (Ministry of the Interior). It was only addressed to domestic care workers who had been working for a family in Italy for at least three months. The employer was asked to show proof of an annual income of at least 20,000 Euros and of having employed the worker for at least three months.

Italy has issued eight regularizations since the beginning of the 1980s: in addition, since 1998, regularizations have been enacted together with the quota system which reserves a number of slots for migrants coming from particular countries of origin and transit, especially those with which Italy has special control and readmission agreements (Sciortino, 2016). The quota system works as a de facto regularization of immigrant workers already in the country (Reyneri, 2003), demonstrating the Italian legislator's ongoing need to root out situations of illegality. In the period from 1998 to 2008, while the numbers of 
asylum applications and migrants arriving by sea were quite contained, the migration flows and quotas established by the flow decrees were generally more sizeable, with some important peaks in correspondence to the years when new laws, amnesties and flow decrees were enacted (Figure 6).

Compared to the 1990s, in the first decade of the 2000s, we can observe an increase in the stock of residence permits issued for remunerated activities, a sharp increase in residence permits for family reasons and a modest increase in the number residence permits for asylum and other humanitarian reasons (Table 1 and Figure 5). As in the past, immigration largely continued to be driven by economic and family reasons, together accounting for more than $92 \%$ of the total residence permits in 2007.

What conclusions can be drawn from this overview of the main policies enacted by the Italian government for the management of immigration and the reasons for and modes of entry to Italy in the two periods of analysis? Italian immigration policies have become more restrictive and have adopted a so-called "securitization" approach within the EU context (Carling, 2002; Geddes and Scholten, 2016; Bendel, 2007; Bonjour, 2011). Political, social and economic reasons, which range from the preservation of cultural identity to the consequences of the more recent international economic recession, such as defence against losing employment, have been put forward by the Italian institutions to restrict the admission of non-citizens and to implement stricter and more punitive policies. On the other hand, as the so-called "policy failure" paradigm argues (Bhagwati, 2003; Cornelius, 2005), immigration policies have limited power (and success) in regulating and controlling migration for several reasons. 1. Structural factors and their consequences, such as socio-economic inequalities, labour market shortages and political conflicts in origin countries cannot be avoided by the receiving countries (Czaika and de Haas, 2013). 2. States have moral duties towards migration since they have to respect international laws and human rights, such as the right to family reunification and the right to asylum (Joppke, 1998; Weiner, 1996). 3. There are economic and demographic needs, such as the employment of young, low-skilled and low-wage workers, which push countries to resort to international migration, at least in the short term. The combination of these factors produces paradoxes and unintended consequences, such as the entry of illegal migrants, their employment in the underground economy, the introduction of amnesties and flow decrees, and the increase in family and humanitarian migration (Paparusso et al., 2017). These consequences make immigration policies quite permissive and often contradictory, such as the Bossi-Fini Law, which allowed the regularization of almost 650,000 immigrants, despite its declared restrictive intentions.

\section{Flow Decrees and Arrivals by Sea: What is Happening Today?}

The international economic crisis has caused the Italian legislator to leave out immigration from the political agenda. As a consequence of the crisis, for two consecutive years, in 2009 and 2010, the flow decrees did not allocate any quota for non-seasonal migration. Later on, with the exception of 2011, the number of immigrants admitted through the quota system was very low compared to the 
past decade, with the total number of immigrants allowed in below 20,000 per year (Figure 6).

Figure 6: Inward Flows by Type in Italy (1998-2016)

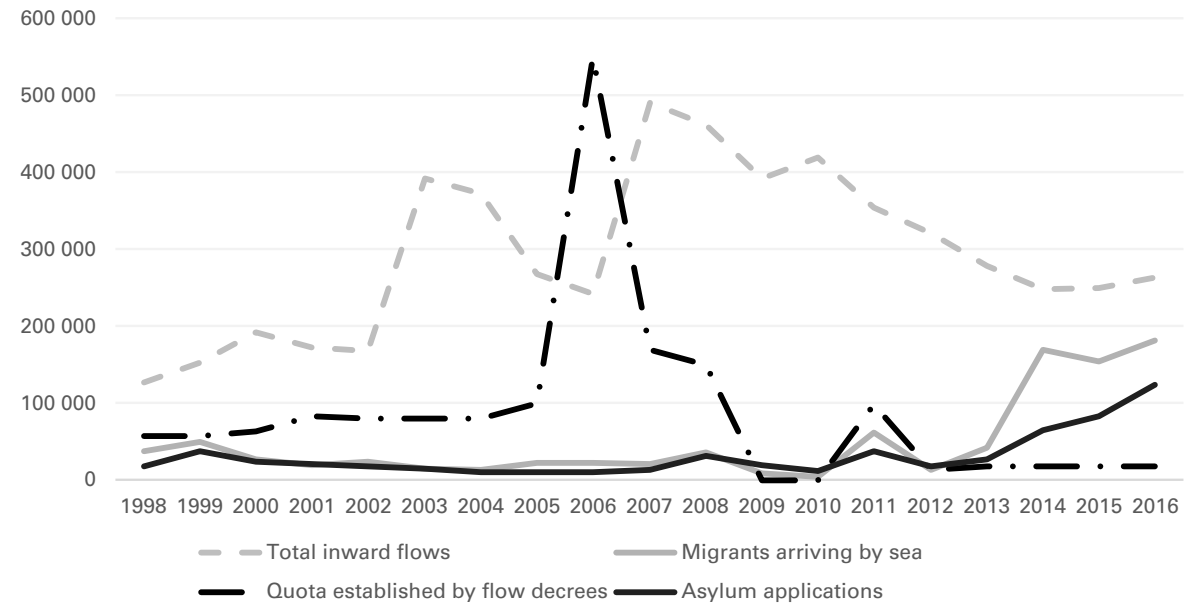

Source: Own elaboration of ISTAT, ISMU and Ministry of the Interior data.

In 2012 (Decree no. 109/2012) an amnesty addressed to illegal non-EU workers and in particular to full-time and domestic workers working at least 20 hours per week was introduced. It regularized 23,000 immigrants (Ministry of the Interior), with the support of their employers who had to provide all the documents and pay 1,000 Euros per worker. In 2014, due to the increased arrival of refugees, the Italian Minister of the Interior issued several "Circolari" (internal documents) and, in agreement with the Italian prefectures, introduced Temporary Reception Centres (CAS), with the aim of improving the management of the migratory emergency. Despite the revisions of the asylum law over the years, the procedures to obtain asylum remain far longer than in other European countries, as demonstrated by the data on the number of persons subject to asylum applications pending at the end of the month, which is the highest in Europe after Germany (Eurostat database). Moreover, once refugee status has been granted, there is a lack of training, job creation initiatives and integration policies for these humanitarian immigrants.

Looking at the number of first residence permits issued by reason between 2007-2015, we notice that since the beginning of the economic crisis in 2008, immigration in Italy has been characterized by a new trend: while first permits issued for work reasons have sharply declined over the years, the number of first permits for family reasons and asylum has increased considerably. At the beginning of the crisis, first residence permits issued for work reasons represented $56 \%$ of the total number of first permits, while in 2015 , first permits issued for work reasons accounted for just 9\% (Figure 7). Conversely, first permits issued for family reasons increased from $32 \%$ to $45 \%$ and first permits for asylum and humanitarian reasons increased from $4 \%$ to $28 \%$. The figures for first residence permits issued by year represent a good approximation of immi- 
gration inflows, even though they only refer to non-EU immigrants. Therefore, for instance, they do not include Romanians, who are the most numerous immigrant community residing in Italy.

While the huge increase in the number of family immigrants, beginning during the 1990s and in the first half of the 2000s, is a consequence of the stabilization of the phenomenon of immigration in Italy, the sharp increase in asylum immigrants is a completely new trend for Italy. The main cause of this new trend is the lack of political and economic stability in most North African and Middle Eastern states due to the Arab Spring. Since 2011, the increase in political instability in countries of the eastern and southern Mediterranean has affected the dynamics of the regional and international migratory flows. Suddenly, Italy started to receive a growing number of asylum seekers: 37,350 in $2011,17,352$ in $2012,26,620$ in 2013, 64,886 in 2014, 83,970 in 2015 and the record number of 123,482 in 2016 . However, while in earlier years they mostly came from northern African and Middle Eastern countries, in the most recent years they have mainly come from sub-Saharan Africa (67\%), the Horn of Africa $(9.2 \%)$, Bangladesh $(9.4 \%)$ and a small part from northern Africa (8.3\%) and Syria (2.1\%). The current situation in Italy does not allow for a clear-cut categorization of refugees and (economic) migrants. In effect, not all the immigrants arriving in Italy since 2011 have applied for asylum (see Figure 6) because the flows are mixed in kind, with highly diverse individual profiles (in terms of gender, age, vulnerabilities, etc.), original motivations or migratory trajectories and experiences, which are difficult to unravel. Therefore, only a small part of the migrants arriving in Italy are entitled to apply for asylum. This is one of the main challenges that policy makers are failing to address both at the Italian and at the European level. Indeed, according to the Italian legislation, immigrants arriving illegally in Italy and not applying for asylum should be repatriated. However, the task of repatriation is neither easy nor painless: it is costly from the economic point of view and operationally complicated as migrants often escape from detention centres. At present, re-opening the Italian borders to regular migration do not seem to be an option for exiting the impasse or re-establishing safe routes for migrants and their families.

Although the use of categories is often misleading, and poverty should be considered a reason for humanitarian migration in the same way as war and persecution (Crawley and Skleparis, 2017), there is a large presence of economic migrants among the humanitarian flows: after all, if European countries decide to close the labour migration channel, migrants will use the even more dangerous channel of humanitarian protection to reach the EU. The distinction between different categories of migrants is difficult because it does not take into account how migratory processes work and that "individuals may change status or simultaneously fit in two (sometimes more) pre-existing categories" (Crawley and Skleparis, 2017: 3). The distinction between categories of migrants and in particular between asylum seekers and economic migrants originates in the dichotomist concept of voluntary and involuntary migration, the first being largely considered the rational decision of individuals in search of better economic conditions, the second being a sudden decision due to unforeseen events such as political instability or war. However, several scholars have shown that the distinction between the two categories is fluid and that a person may change status and category several times during his/her lifetime (Jeandesboz 
and Pallister-Wilkins, 2014). The development of new concepts such as "mixed flows" (as well as "mixed motivations" and "transit migration") is useful to overcome the binary and static distinction between the two categories of migrants and refugees. The evolution of migration flows presented in Figures 6 and 7 demonstrates that while economic migration is increasingly restricted in Italy, thus proving the lack of an active immigration policy (Sciortino, 2016), family and humanitarian migration is the main entry channel to the country (Bosh, 2015). These considerations lead us to argue that the so-called southern European model of immigration has expanded over time, as regards the reasons for and the modes of entry.

Figure 7: Distribution (in \%) of First Residence Permits Issued by Motive in Italy (2007-2015)

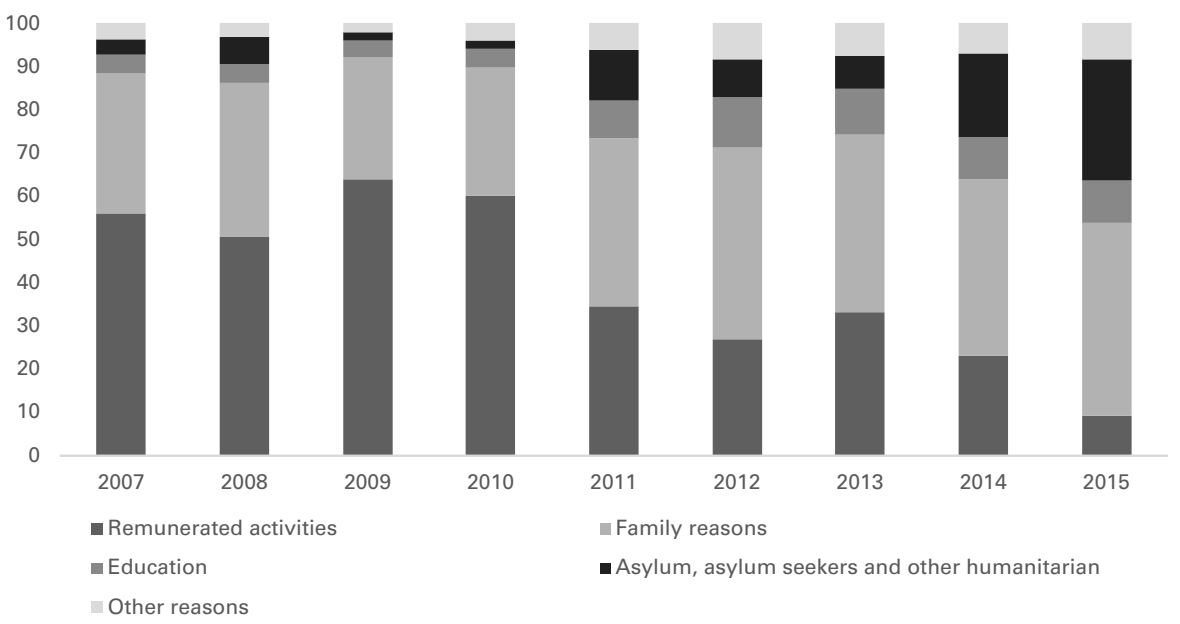

Source: Own elaboration of ISTAT data.

\section{Discussion and Conclusion}

The EU's political response to the "migration crisis" has been considered quite weak and fragmented. It has mainly consisted of the "hotspot approach" in Italy and Greece (May 2015), intra-EU relocation schemes (September 2015), resettlement schemes (July 2015), the EU-Turkey agreement (March 2016) and the Malta Declaration (February 2017). The last two initiatives present a series of limitations: for instance, the EU-Turkey agreement goes against fundamental $\mathrm{EU}$ values, such as the respect of human solidarity and protection; it violates the second paragraph of Article 13 of the Universal Declaration of Human Rights of 1948 , according to which "Everyone has the right to leave any country, including his own, and to return to his country"; and it considers that Turkey is a safe country, without taking its economic and political instability into account. The Malta Declaration is also a tool that uses Libya as the main contractor to filter the arrival of immigrants to Europe using the Libyan Coast Guard to help the EU control its coasts and rescue immigrants. As in the past, Europe is making bilateral agreements with "safe" third countries to contain and readmit illegal immigrants. These initiatives are similar to previous policies adopted by the EU 
to prevent immigration, showing a continuity in the management of migration. The experience of other immigration countries tells us that such policies have already proven to be ineffective in containing immigration and to be particularly effective in consolidating criminal organizations and illegal trafficking (Castles, 2004). However, the long-term dimension of the immigration phenomenon is largely ignored at the European level and the political answers are emergency-oriented, preferring short-term management of the immigrants' entry and permanence. Possible solutions to the "crisis" such as implementing the 2001 European directive on temporary protection for immigrants not fitting the criteria of the Geneva Convention or opening legal channels of labour migration in order to prevent immigrants from illegally crossing borders at peril of their lives, as well as human trafficking and smuggling, are not even considered (Wihtol de Wenden, 2017).

The "migration crisis" has led Italy to ask for more cooperation and solidarity from the EU, but at the same time to resort to some of its own initiatives, such as the Mare Nostrum Operation (2013-2014) to protect its external borders and to help migrants crossing the Mediterranean Sea in unsafe conditions and the Migration Compact (2016) which proposed an old recipe, that is, a multilateral policy on cooperation and development with the migrants' origin and transit countries. It introduced a new measure, however: the possibility of European military taskforces intervening directly in the management of migration and repatriation to the African continent. In other words, it is a policy to externalize and extra-territorialize the migration movements. Finally, the Minniti Decree, approved in April 2017, to enhance public security especially with respect to the nomads and illegal migrants living in Italian cities, aimed to speed up the application process for asylum seekers, to distinguish between them and illegal migrants, and to avoid double applications, in line with the provisions of the Dublin Convention.

Italy is facing the same dilemma as Europe: there is a growing number of immigrants arriving illegally in Italy that cannot apply for asylum $(61 \%$ of those who arrived in 2016 were not entitled to apply for asylum), however, labour migration channels have been closed since 2009. Immigrants arriving in Italy and not entitled to apply for asylum are not repatriated because the agreements with the country of origin adopted in the past are no longer effective and because repatriations are costly operations; thus they stay illegally in the country, working in the underground economy in the hope of being regularized in the next amnesty. The solution, like in the case of Europe, is to re-open legal immigration channels and plan a yearly quota for labour migration. Such an option is advantageous not only for the immigrants but also for the countries of destination, which can benefit from legal migration both from the economic and socio-demographic points of view.

The situation of asylum seekers is also precarious because they face long, perilous and costly journeys to arrive in Italy and once they arrive the procedures are long and discretional. The opening of humanitarian corridors, sponsorships and effective screening mechanisms (e.g. temporary visas) would prevent them from risking the dangerous crossing of the Mediterranean by boat.

The long history of immigration policy in Italy shows that the debate around 
international migration has been constantly accompanied by the dichotomy between the "economic acceptance of immigration" and the "political rhetoric of growing hostility and apparent closure" (Ambrosini, 2013: 176). Indeed, to deal with labour market shortages, employers started to hire foreigners, a special case being those families that have hired thousands of both male and female immigrants to care for children and the elderly. We can argue that until the beginning of this decade, recognition of the economic role of immigrants provided political and social legitimacy for their presence in Italy. However, since 2011 the perception of immigration as a security and public order problem has prevailed over economic acceptance. Italian governments, irrespective of their political party, support this view of immigration, making a clear distinction between asylum seekers and economic immigrants. Until now, immigrants have consistently responded to the demand for labour in the industry, care and services sectors in Italy and more broadly, they have contributed to its economic productivity. Employers have received much power in this process, as intermediaries between immigrants and the labour market niches (Triandafyllidou and Ambrosini, 2011). Moreover, immigrants have contributed to slowing down population ageing and the decline in fertility. The re-opening of legal immigration channels through regularization or the re-introduction of the quota system, not only as an ex-post instrument of regularization of immigrants already present in Italy, but also as formal planning of the foreign labour force, will help Italy to cope with its domestic shortages, in particular with the segmentation of the labour market and structural demographic ageing. Moreover, it will help to formally recognize the phenomenon of immigration as structural and not transitory, and above all to mitigate negative attitudes towards migrants, which are generally being exacerbated by a political discourse dominated by security issues. As a result, this would foster the migrants' social acceptance in Italian society and a mutual process of solidarity and integration (Panichella and Ambrosini, 2018). To conclude, we argue that the southern European model of immigration has expanded over time, as regards the reasons for and the modes of entry. This is due to the securitization of immigration and the increased number of asylum seekers. However, taking into account the data on labour market integration, the data on the number of illegal immigrants resident in Italy and the policy adopted by the Italian governments, we can argue that the southern European model is still the right theoretical framework for describing the situation in Italy because its main common characteristics provide a detailed and well-adapted picture of immigration to Italy. 


\section{References}

Ambrosini Maurizio (2013) Immigration in Italy: Between Economic Acceptance and Political Rejection, Journal of International Migration and Integration, 14 (1), pp. 175-194.

Arango Joaquín and Finotelli Claudia (2009) Past and Future Challenges of a Southern European Migration Regime: the Spanish Case, IDEA Working Paper, $\mathrm{n}^{\circ} 8$, pp. 1-44.

Baganha Maria I. (1998) Immigrant involvement in the informal economy: the Portuguese case, Journal of Ethnic and Migration Studies, 24 (2), pp. 367-385.

Baldwin-Edwards Martin and Arango Joaquín (Eds.) (1999) Immigration and Informal Economy in Southern Europe, London, Routledge, 280 p.

Bendel Petra (2007) Everything under Control? The European Union's Policies and Politics of Immigration, in Thomas Faist and Ette Andreas Eds., The Europeanization of National Policies and Politics of Immigration, Basingstoke, Palgrave Macmillan, pp. 32-48.

Bhagwati Jagdish (2003) Borders beyond Control, Foreign Affairs, 82 (98), pp. 98-104.

Bonjour Saskia (2011) The Power and Moral of Policy Makers: Reassessing the Control Gap Debate, International Migration Review, 45 (1), pp. 89-122.

Bosh Peter (2015) Towards a pro-active European labour migration, Policy Briefs, 3, pp. 1-16.

Carling Jørgen (2002) Migration in the Age of Involuntary Immobility:Theoretical Reflections and Cape Verdean Experiences, Journal of Ethnic and Migration Studies, 28 (1), pp. 5-42.

Castles Stephen (2004) Why Migration Policies Fail, Ethnic and Racial Studies, 27 (2), pp. 205-227.

Colombo Asher and Sciortino Giuseppe (2004) Gli Immigrati in Italia, Bologna, II Mulino, $144 \mathrm{p}$.

Cornelius Wayne A. (2005) Controlling "Unwanted" Immigration: Lessons from the United States, 1993-2004, Journal of Ethnic and Migration Studies, 31 (4), pp. 775-794.

Crawley Heaven and Skleparis Dimitris (2017) Refugees, migrants, neither, both: categorical fetishism and the politics of bounding in Europe's "migration crisis", Journal of Ethnic and Migration Studies, pp. 1-17.

Czaika Mathias and de Haas Hein (2013) The Effectiveness of Immigration Policies, Population and Development Review, 39 (3), pp. 487-508.

Di Bartolomeo Anna, Gabrielli Giuseppe and Strozza Salvatore (2016)The Labour Market Insertion of Immigrants into Italy, Spain and the United Kingdom. Similarities and Differences and the Southern European Model of Migration, in Elena Ambrosetti, Donatella Strangio and Catherine Wihtol de Wenden Eds., Migration in the Mediterranean. Socio-Economic Perspectives, London, Routledge, pp. 57-84.

Einaudi Luca (2007) Le politiche dell'Immigrazione in Italia dall'Unità ad Oggi, Roma/Bari, Editori Laterza, 444 p. 
Eurostat (2017) Online database, [online] last checked on 19/04/2017. URL: http://ec.europa.eu/eurostat/tgm/table.do?tab=table\&init=1\&language=en\&pcode $=$ tps00190\&plugin $=1$

Fellini Ivana and Fullin Giovanna (2016) The South-European Model of Immigration, in Elena Ambrosetti, Donatella Strangio and Catherine Wihtol de Wenden Eds., Migration in the Mediterranean. Socio-Economic Perspectives, London, Routledge, pp. 32-56.

Freeman Gary P. (1995) Modes of Immigration Politics in Liberal Democratic States, International Migration Review, 29 (4), pp. 881-902.

Geddes Andrew and Scholten Peter (2016) The politics of Migration and Immigration in Europe, London, Sage, 288 p.

Italian Ministry of Interiors (2017) Online database, [online] last checked on 19/09/2017. URL: http://www.interno.gov.it/it/sala-stampa/dati-e-statistiche

ISTAT (Italian National Institute of Statistics) (2017) Online database, [online] last checked on 20/09/2017. URL: http://demo.istat.it/index_e.html

ISMU Foundation (Initiatives and Studies on Multi-ethnicity) (2017) Online database, [online] last checked on 07/09/2017. URL: http://www.ismu.org/2014/11/ numeri-immigrazione/

Jeandesboz Julien and Pallister-Wilkins Polly (2016) Crisis, Routine, Consolidation: The Politics of the Mediterranean Migration Crisis, Mediterranean Politics, 21 (2), pp. 316-320.

Jeandesboz Julien and Pallister-Wilkins Polly (2014) Crisis, enforcement and control at the EU borders", in Anna Lindley Ed., Crisis and migration: critical perspectives, London, Routledge, pp. 115-135.

Joppke Christian (1998) Why Liberal States Accept Unwanted Immigration, World Politics, 50 (2), pp. 266-293.

King Russel, Lazaridis Gabriella and Tsardanidis Charalambos (Eds.) (2000) Eldorado or Fortress? Migration in Southern Europe, Basingstoke, Palgrave Macmillan, $351 \mathrm{p}$.

OECD (2005) International Migration Outlook 2006, Paris, Oecd Publishing, 328 p.

Panichella Nazareno and Ambrosini Maurizio (2018) Between Fears, Contacts and Family Dynamics: the Anti-immigrants Attitudes in Italy, Journal of International Migration and Integration, pp. 1-21.

Paparusso Angela, Tineke Fokkema and Elena Ambrosetti (2017) Immigration Policies in Italy: Their Impact on the Lives of First-Generation Moroccan and Egyptian Migrants, Journal of International Migration and Integration, 18 (2), pp. 499-546.

Pastore Ferruccio, Monzini Paola and Giuseppe Sciortino (2006) Schengen's Soft Underbelly? Irregular Migration and Human Smuggling across Land and Sea Borders to Italy, International Migration, 44 (4), pp. 95-119.

Pastore Ferruccio and Villosio Claudia (2011) Nevertheless Attracting. Italy and Immigration in Times of Crisis, LABOR Working Paper $N^{\circ} 106$, Turin, LABOR. 
Peixoto Joao, Arango Joaquin, Bonifazi Corrado, Finotelli Claudia, Sabino Catarina, Strozza Salvatore and Triandafyllidou Anna (2012) Immigrants, Markets and Policies in Southern Europe. The Making of an Immigration model?, in Marek Okólski Ed., European Immigrations. Trends, Structures and Policy Implications, IMISCOE Research, Amsterdam, Amsterdam University Press, pp. 107-147.

Reyneri Emilio (2003) Immigration and the underground economy in new receiving South European countries: manifold negative effects, manifold deeprooted causes, International Review of Sociology, 13 (1), pp. 117-143.

Reyneri Emilio (2001) Migrants' Involvement in Irregular Employment in the Mediterranean Countries of the European Union, Geneva, International Labor Organization, $66 \mathrm{p}$.

Reyneri Emilio (1998) The role of the Underground Economy in Irregular Migration to Italy: Cause or Effect?, Journal of Ethnic and Migration Studies, 24 (2), pp. 313-331.

Sciortino Giuseppe (2016) Immigration, in Erik Jones and Gianfranco Pasquino Eds., Oxford Handbook of Italian Politics and Society, Oxford, Oxford University Press, pp. 633-644.

Triandafyllidou Anna and Ambrosini Maurizio (2011) Irregular Immigration Control in Italy and Greece: Strong Fencing and Weak gate-keeping Serving the Labour Market, European Journal of Migration and Law, 13, pp. 251-273.

UNHCR (United Nations High Commissioner for Refugees) (2017) Online database, [online] last checked on 05/09/2017. URL: http://popstats.unhcr.org/en/ overview

Weiner Myron (1996) Ethics, National Sovereignty and the Control of Immigration, International Migration Review, 30 (1), pp. 171-197.

Wihtol de Wenden Catherine (2017) Actual Patterns of Migration Flows: The Challenge of Migration and Asylum in Contemporary Europe, in Andreas Grimmel and Susanne Giang Eds., Solidarity in the European Union. A Fundamental Value in Crisis, Cham, Springer, pp. 67-79.

Wihtol de Wenden Catherine (2013) Gouvernance mondiale, une graine d'espoir ?, Projet, 4 (335), pp. 40-49.

Wihtol de Wenden Catherine and Ambrosetti Elena (2016) Borders, Refugees and Migration: What Right to Mobility in the Mediterranean?, Rivista Italiana di Economia Demografia e Statistica, 70 (2), pp. 5-13.

Zincone Giovanna (2006) The making of Policies: Immigration and Immigrants in Italy, Journal of Ethnic and Migration Studies, 32 (3), pp. 347-375.

Zincone Giovanna (1998) Illegality, Enlightenment and Ambiguity: a Hot Italian Recipe, South European Society and Politics, 3 (3), pp. 45-82.

Zincone Giovanna and Tiziana Caponio (2006) Immigrant and immigration policy-making:The case of Italy, IMISCOE Working Papers, pp. 1-20. 


\section{Elena Ambrosetti and Angela Paparusso}

\section{Migrants or Refugees? The Evolving Governance of Migration Flows in Italy during the "Refugee Crisis"}

Since the beginning of its experience as an immigration country, Italy has received only small numbers of asylum-seekers. Until the late 2000s, with the reception of EU directives on asylum, Italy had hardly any comprehensive normative framework on asylum. The so-called refugee crisis initiated in the second half of 2013, with hundreds of thousands people crossing the Mediterranean to reach Italy, has decisively changed these features. In such a context, how have Italian policies reacted to the increasing magnitude and complexity of mixed flows across the Mediterranean? Has Italy turned from a labour migration magnet to an asylum land? In this paper, we will address these questions by presenting the evolution of migration flows and stocks in Italy in the last decade and by analysing the policy responses adopted by Italian authorities. Lastly, we will highlight the role of the EU in influencing the Italian asylum and migration policies.

\section{Migrants ou réfugiés ? L'évolution de la gouvernance des flux migratoires en Italie au cours de la « crise des réfugiés "}

Depuis le début de son expérience en tant que pays d'immigration, I'Italie n'a reçu qu'un petit nombre de demandeurs d'asile. Jusqu'à la fin des années 2000, avec la réception des directives de I'UE sur l'asile, I'Italie n'avait guère de cadre normatif complet sur l'asile. La crise dite des réfugiés, initiée au second semestre 2013, a changé de manière décisive ces caractéristiques. Dans un tel contexte, comment les politiques italiennes ont-elles réagi face à l'ampleur et à la complexité croissante des flux mixtes à travers la Méditerranée ? L'Italie est-elle devenue un pays d'asile? Dans cet article, nous aborderons ces questions en présentant l'évolution de la migration en Italie au cours de la dernière décennie et en analysant les réponses politiques adoptées par les autorités italiennes. Enfin, nous soulignerons le rôle de I'UE dans les politiques italiennes en matière d'asile et de migration.

\section{¿Migrantes o refugiados? La evolución de la gobernanza de los flujos migratorios en Italia durante la "crisis de los refugiados"}

Desde el comienzo de su experiencia como país de inmigración, Italia solo ha recibido un pequeño número de solicitantes de asilo. Hasta finales de la década de 2000, con la recepción de las directivas de la UE sobre el asilo, Italia apenas tenía un marco normativo integral sobre el asilo. La llamada crisis de refugiados iniciada en la segunda mitad de 2013 ha cambiado estas características de manera decisiva. En ese contexto, ¿cómo han reaccionado las políticas italianas a la creciente magnitud y complejidad de los flujos mixtos en el Mediterráneo? ¿Ha pasado Italia de un centro de atracción para trabajadores manual a una tierra de asilo? En este documento, abordaremos estas cuestiones presentando la evolución de los flujos migratorios y las poblaciones en Italia en la última década y analizando las respuestas políticas adoptadas por las autoridades italianas. Por último, destacaremos el papel de la UE para influir en las políticas italianas de asilo y migración. 